\title{
Comparative Study on Indoor Thermal Environment in Winter of Two Tibetan Dwellings
}

\author{
SUOLANG Baimu ${ }^{1, a}$, HE Quan, ${ }^{2, b}$ and LIU Jiaping ${ }^{3, c}$ \\ ${ }^{1}$ Tibet University, Lhasa ,China \\ ${ }^{2}$ Xi'an University of Architecture and Technology, Xi'an 710055, China \\ ${ }^{3}$ Xi'an University of Architecture and Technology, Xi'an 710055, China \\ a29657650@qq.com, b76634259@qq.com, cjiaping1956@qq.com
}

Keywords: Tibetan dwelling; indoor thermal environment; solar energy use; winter thermal environment

\begin{abstract}
Traditional Tibetan dwelling is a unique building style formed in the plateau environment. Due to technical and economic limits, traditional Tibetan dwellings perform insufficiently to face the high comfort requirements of contemporary life under cold climate. In this paper, we selected two typical dwellings, located in Chamdo Region and Kangding County respectively, to carry out the indoor thermal environment measurement in winter, and to optimize the design methods of residential houses. The results of this comparative studu shows that under similar conditions of solar radiation, the indoor thermal environment is better in Kangding residential house is. The differences in building layout, envelope material and solar energy usage are the primary reasons for this phenomenon.
\end{abstract}

\section{Introduction}

Tibetan plateau, with its fragile ecological environment, is regarded as one of the world's harshest living environment. In the long history of Tibet, the local residents have built traditional dwellings with limited materials and technologies coping extreme climates . Extremely low ecological cost was used to meet the basic survival and multiplied needs of Tibetan in snowy plateau. However, these traditional local living conditions are not comfortable with today's building standards. With the growth of economy and improvement of living quality, local residents strive for better living condition.

This study took physical environment measurement of dwellings in Chamdo Region, Tibet Autonomous Region and in Kangding County, Sichuan Province separately, in December 2012 and January, 2013. The research has gained basic data which is useful in improving winter indoor thermal environment of local residential houses.

\section{Methods}

Study area. Resident house A is in No. 184-1, Qiya Street Community, Chamdo Region, Tibet Autonomous Region. Figure 1 shows that the house has a courtyard. The living room with the function of kitchen (room A-1), rental rooms and storage are on floor one. The bedroom, prayer room and storage are on floor two, with some rental rooms capped by wood. The material of exterior walls on floor one is masonry. The thickness of stone is $550 \mathrm{~mm}$. The interior walls are made of adobe. The second floor is made of concrete hollow blocks with a thickness of $200 \mathrm{~mm}$. A burning stove is settled in the kitchen for heating and cooking with woods during the whole day. Other rooms have no heating facilities

Resident house B is in Xiamalong Village, Tagong, Kangding Country, Ganzi Prefecture, Sichuan Province. Figure 2 shows that the house has a line-shaped layout and is neatly shaped. The two-story house is under a mixture structure of stone and wood. The thickness of the stone wall is 700 $\mathrm{mm}$ at the height of $1.5 \mathrm{~m}$ on the first floor. Floor one has the rental rooms and a storage. Floor two 
contains a living room, a bedroom and a storage. The living room with the function of a kitchen (room B-5) uses a stove to offer intermittent heating. Its fuel is wood. Other rooms have no heating facilities.

Meteorological measurements. Measurements for house A were taken from January 10 to 11 in 2013. The survey days were sunny. Measurements for resident house B were taken from December 24 to 25 in 2013. The survey days were wainly sunny with partly cloudy. The direct and diffuse solar radiation, outdoor air temperature, outdoor air humidity, indoor air temperature and humidity for the main room were measured at 30-min intervals.

A solar radiometer (TBD-1, China) with an accuracy of $8.789 \mu \mathrm{V} /\left(\mathrm{W} \cdot \mathrm{m}^{-2}\right)$ was placed horizontally on the roof of the residential houses without any shelter. The air temperature was monitored with TR7xU140E thermo-hygrometers (T\&D, Japan) with an accuracy of $0.2{ }^{\circ} \mathrm{C}$ automatically. The positions of thermo-hygrometers indoor were presented in Figure 1 and Figure 2. The outdoor measuring points were positioned in the shading area on the roof, and the equipment was sheltered with tinfoil.
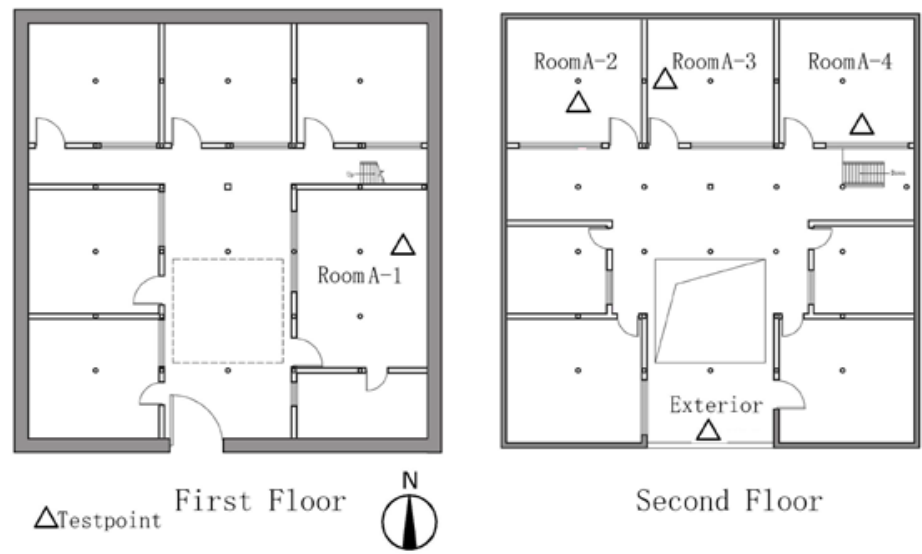

Second Floor

Fig.1 The layout of house A and the positions of measuring points
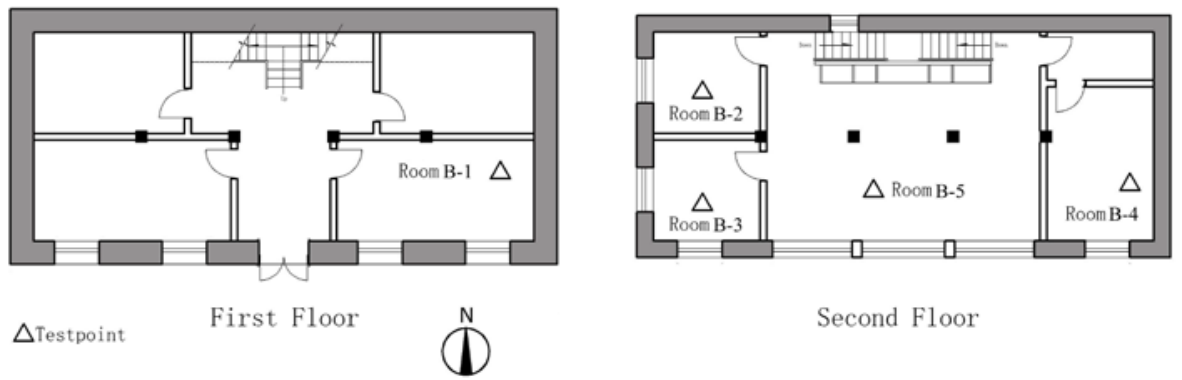

Second Floor

Fig.2 The layout of house $\mathrm{B}$ and the positions of measuring points

\section{Results and Discussion}

Outdoor thermal condition. During the test period, the average global solar radiation was $286.22 \mathrm{~W} / \mathrm{m}^{2}$ in Chamdo Region, and was $285 \mathrm{~W} / \mathrm{m}^{2}$ in Kangding County. The maximum values of global solar radiation in two regions were $708.84 \mathrm{~W} / \mathrm{m} 2$ and $491.52 \mathrm{~W} / \mathrm{m}^{2}$, respectively. The average values of direct solar radiation were $206.26 \mathrm{~W} / \mathrm{m}^{2}$ and $191.32 \mathrm{~W} / \mathrm{m}^{2}$, and the maximum values were $615.54 \mathrm{~W} / \mathrm{m}^{2}$ and $414.15 \mathrm{~W} / \mathrm{m}^{2}$ (Fig.3 and Fig.4). The mean values of global solar radiation and direct solar radiation are roughly equal in two locations during the test, while the peak values were higher in Chamdo Region. The direct solar radiation takes about $72 \%$ of the total radiation in Chamdo Region, while this percentage is $67 \%$ in Kangding County. The result indicates that the sunlight condition is better in Chamdo Region. 


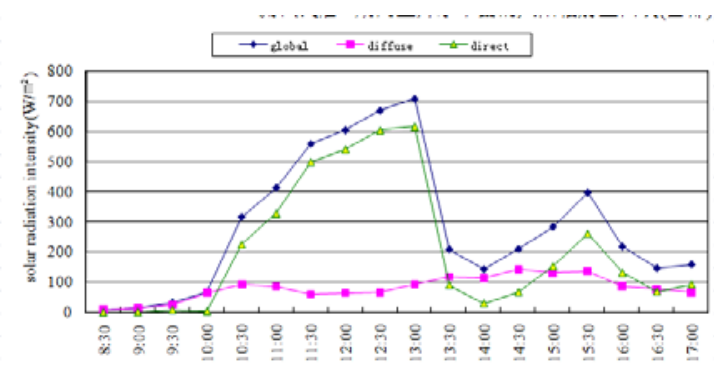

Fig.3 Solar radiation intensity in Chamdo Region (house A)

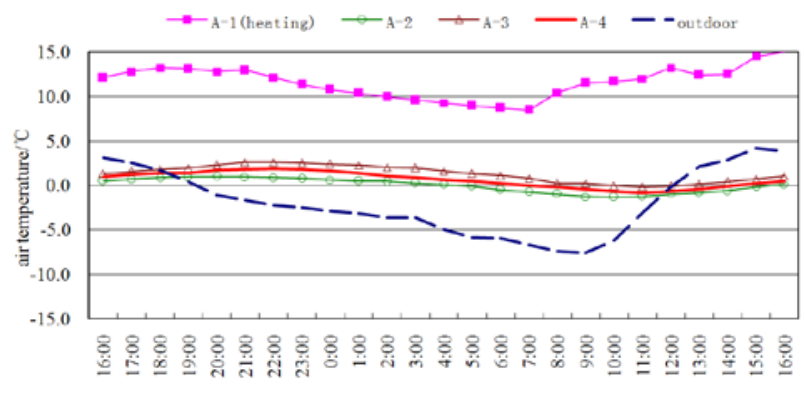

Fig.5 Air temperature curves for house A

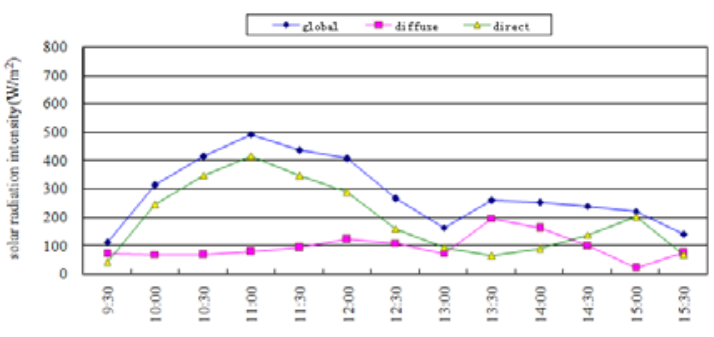

Fig.4 Solar radiation intensity in Kangding County (house B)

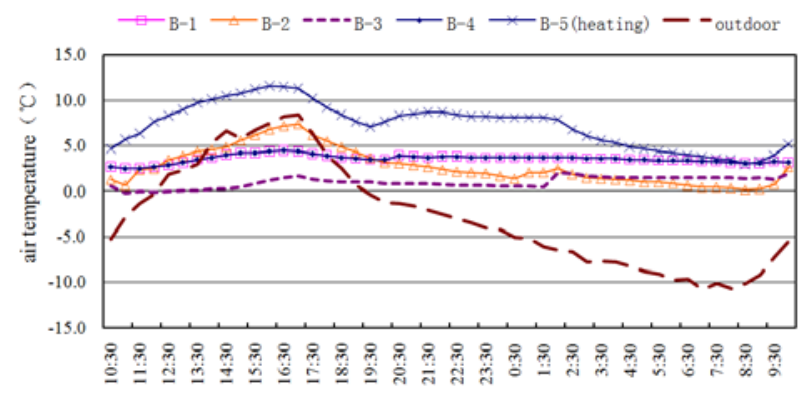

Fig.6 Air temperature curves for house B

Fig. 5 shows that the average outdoor air temperature in house $\mathrm{A}$ was $-1.9^{\circ} \mathrm{C}$. The maximum value of air temperature was $4.2^{\circ} \mathrm{C}$ at $15: 00$ and the minimum value of air temperature was $-7.6^{\circ} \mathrm{C}$ at 9:00. The amplitude of outdoor air temperature was $11.8^{\circ} \mathrm{C}$. Fig. 6 shows that the average outdoor air temperature in house $\mathrm{B}$ was $-2.5^{\circ} \mathrm{C}$. The maximum value of air temperature was $8.4^{\circ} \mathrm{C}$ at $17: 00$ and the minimum value of air temperature was $-10.8^{\circ} \mathrm{C}$ at $7: 00$. The amplitude of outdoor air temperature was $19.2^{\circ} \mathrm{C}$. This means during the measuring period, the surrounding of house $\mathrm{B}$ was colder than house $\mathrm{A}$, and the variation of outdoor air temperature was more intense in house $\mathrm{B}$.

Indoor air temperature. Kitchens with intermittent heating for the two houses were A-1 and B-5, and their maximum values of air temperature were $15.1{ }^{\circ} \mathrm{C}$ and $11.6{ }^{\circ} \mathrm{C}$ respectively, and the average air temperatures were $11.6{ }^{\circ} \mathrm{C}$ and $7.3{ }^{\circ} \mathrm{C}$.

The figures above show the comparison of indoor air temperature in non-heating rooms of the two testing houses, in order to understand the thermal performance of building envelopes without the interference of stoves and other heat sources. The maximum air temperature was $2.6{ }^{\circ} \mathrm{C}$ (room A-3) and $7.4{ }^{\circ} \mathrm{C}$ (room B-3) in both houses. In residential house $\mathrm{A}$, the mean air temperature was $0.0^{\circ} \mathrm{C}$ in room $\mathrm{A}-2,1.3^{\circ} \mathrm{C}$ in room $\mathrm{A}-3$, and $0.6^{\circ} \mathrm{C}$ in room $\mathrm{A}-4$. While in house $\mathrm{B}$, the mean air temperature was $2.8^{\circ} \mathrm{C}$ in room $\mathrm{B}-1,1.0^{\circ} \mathrm{C}$ in room $\mathrm{B}-2,2.8^{\circ} \mathrm{C}$ in room $\mathrm{B}-3$, and $3.6^{\circ} \mathrm{C}$ in room $\mathrm{B}-4$.

Analysis of field data. The average indoor air temperature for the heating room in these two houses was $11.6{ }^{\circ} \mathrm{C}$ and $7.3{ }^{\circ} \mathrm{C}$, while the average indoor air temperature for non-heating rooms didn't exceed $4.3{ }^{\circ} \mathrm{C}$. These values did not reach the standard of comfortable environment, indicating the environment of indoor was cold, and the insulation capabilities of the building envelope were inadequate. Temperature fluctuations of non-heating rooms for these two houses were small, indicating the great ability of thermal storage for stone masonry.

The comparison of field measurement shows that the average outdoor temperature for residential house B during the testing periods was lower than house A, and the fluctuation of air temperature was greater. Generally, the indoor air temperature of non-heating rooms (B-1, B-3, and B-4) in house B was higher than that in house A, excluding the room B-2 in the northwest corner. This result indicates that the thermal performance of building envelope in house $\mathrm{B}$ is better than that in house $\mathrm{A}$. 
The highest value of the outdoor air temperature appeared at 15:00 for house $\mathrm{A}$, and the maximum value of solar radiation appeared at 13:00. For non-heating rooms, the maximum air temperature occurs after 20:00 at night, which are less affected by solar radiation and largely affected by the artificial movement. The result means the use of solar energy is at a low level in residential house A.

The air temperature in room B-2 at the north side was significantly lower than the other room facing south in residential house B. This room, as well as stairs, storage, and other rooms at the north side, was "temperature buffer zone" for the rooms at the south side. In addition, the maximum temperature for non-heating rooms at the south side (B-1,B-3, and B-4) appeared in the afternoon. This phenomenon is due to the direct solar radiation through the windows, which contribute the indoor thermal environment greatly.

\section{Summary}

Comparing the thermal conditions in winter for two residential houses in Chamdo Region and Kangding County, the result indicates that house B has a better thermal environment than house A in colder climate. The main reasons are as follows:

(1) House A in Chamdo Region follows the historical layout with a square form, which was designed for defense. All rooms have windows inward the patio. Shelter conditions between windows are serious. Local residents do not have a strong awareness of using solar energy. All these reasons result in the terrible indoor thermal conditions in winter for house A.

(2) House B has a smaller shape coefficient so its layout seems more reasonable. The living room and the main bedroom are located at the south side. The second bedroom, the storage and the corridors are at the north side of the building, which fun tron as a buffer of air temperature. Additionally, windows in the south wall are big enough with no obstruction, forming a passive solar heating. The above reasons benefit the thermal conditions in the house and increase the maximum temperature of the rooms.

(3) The material of the exterior wall for house A in Chamdo Region on floor one is stone with a thickness of $550 \mathrm{~mm}$, and on floor two is concrete hollow blocks with a thickness of $200 \mathrm{~mm}$. The material of the exterior wall for house B is stone wall of $700 \mathrm{~mm}$ thick. So the ability of heat insulation and storage of building enclosure for house $\mathrm{B}$ is better.

\section{Acknowledgments}

We would like to thank the National Natural Science Foundation of China (No. 51208420) and the National Science \& Technology Pillar Program during the Twelfth Five-year Plan Period (No. 2013BAJ03B04-1)for financial support.

\section{References}

[1] SHEN Gao-feng, BAI Wen-feng: Research on improving thermal environment of Shangri-La Tibetan dwellings based on the use of passive solar energy. Jiangxi Science Vol.30 (2012),p. 338-342

[2] Liu Yanfeng, Liu Jiaping, Yang Liu, et al: Measuring study of passive solar house for traditional dwelling building in Lhasa area. Acta Energlae Solaris Sinca, Vol.29 (2008), p. 393

[3] Liu Jiaping, Yang Liu, Liu Yanfeng: Key technological research and application of low energy consumption building design in Tibet. Engineering Sciences. Vol. 13 (2011), p. 40-46

[4] Huang Lingjiang, Leng Yuhan: Field study of winter indoor thermal environment of traditional dwelling in Nyingchi, Tibet. South Architecture. Vol.1 ( 2012), p. 92-96

[5] Muya Qujijiancai: Tibetan dwellings ( China Architecture \& Building Press, Beijing 2009). 